\title{
UNIVERSITY UNDERGRADUATES' ATTITUDES ON CODE-MIXING AND SEX STEREOTYPES
}

\author{
Chao-chih Liao \\ Yu-hwei E. Lii-Shih
}

\section{Introduction}

Mandarin Chinese is the high language in Taiwan; Taiwanese is the low. Taiwanese does not have the standardized written form. Many laymen even say that Taiwanese does not have the written form. English is the most widely learned foreign language in Taiwan, and Japanese is the second widely learned. Besides the fact that Japanese is the second widely learned foreign language, it was the 'national' language from 1895 to 1945 when Taiwan was under the control of Japan; therefore, the Taiwanese born before 1940 or so could speak either fluent Japanese or a little Japanese. In other words, people over 50 years old may be able to speak Japanese.

In modern Taiwan, not only the mixing use of Mandarin and Taiwanese is very prevalent, but the mixing use of Mandarin and English and that of Mandarin and Japanese are also very popular. This phenomenon does not only exist in the educational domain (Liao 1992), but it also exists in the videotape shows made by the most profitable actor Zhu Ge-liang, who earns more than two million US dollars per year. Zhu's videotapes are mainly to entertain the working class in Taiwan. They are often shown on the deluxe tour bus; and intellectuals or university students often consider them as entertainment for the lower classes.

It has been a fashion for the past two or three years that there is heavy code-mixing of Mandarin and Taiwanese, Mandarin and English, and sometimes, there is code-mixing of Mandarin and Japanese on TV programs depicting modern life. On these programs, the major language used is still Mandarin. Recently on a TV program depicting modern life, we heard one actor say,

\section{Ni jiao ta get out. ${ }^{1}$ \\ 'You tell him to get out.'}

He announced that he felt reluctant to ask him to get out in Mandarin, so he spoke English "get out". It is sometimes a common phenomenon, that an English equivalent is sometimes used as a euphemism for Chinese taboos. To shout gwen-dan is harsh to the ear; it should be avoided. Therefore the English equivalent "get out" is used instead.

${ }^{1}$ The pin-yin romanization system is used in transliterate the Mandarin Chinese character into Enlgish. The digits $0,1,2,3$, and 4 put after the Chinese phonetic symbols stand for the neutral, first, second, third, or fourth tone of the preceding Chinese character. 
Sometimes, in professors' lectures in the academic setting, the insertion of English terms is to show that the professor is well-learned. The insertion of Taiwanese terms shows that the professor wants to make the teacher-student relationship closer. It is also possible that the professor habitually mixes Mandarin, Taiwanese, and English. In the academic setting, we ask our colleagues whether they have ever inserted Taiwanese words or phrases or sentences into the otherwise all Mandarin lectures. Most of them give us positive answers and explain that their motivation is to make students laugh and thus to prevent them from falling asleep in class. It is a common phenomenon that teachers use code mixing to reach a humorous effect.

Though the mixing of different codes is widely used in Taiwan, a systematic study of this is hard to find. The studies on code mixing in Taiwan have mainly been about the mixing of Mandarin and Taiwanese only (e.g. Kubler 1988; Lin 1987; Yeh 1989; Cheng 1989). Of course, this kind of mixing is more widely used compared with that of Mandarin and English as well as Mandarin and Japanese.

It has been a universal idea that the same person in different guises of language is judged differently. When the speaker speaks in one code, s/he will receive more support or cooperation from the audience than if $s /$ he would speak in another code.

Language serves both unifying and separating functions for sociocultural groups. The unifying and separatist functions are most likely to be fulfilled by the low language (Ferguson 1959; Fasold 1984: 158). This paper aims at the language attitudes of the three mixings of Mandarin plus English, Mandarin plus Japanese, and Mandarin plus Taiwanese, and the pure Mandarin.

In this study, we also take gender into consideration. In the human world, it seems that man is the "default person", while woman is "marked". Bate (1988) states that the dictionary meanings listed for the word woman make clear that both its denotations and connotations center on woman's sexual nature and her functions in relation to other people. Mistress, wife, paramour, servant, fickle partner, or revealer of "the woman in" a man - in all of these cases what defines a woman is her relatedness, and primarily her relationships to men (p. 83). Lakoff (1973) says that

"that women are systematically denied access to power, on the grounds that they are not capable of holding it as demonstrated by their linguistic behavior along with other aspects of their behavior; and the irony here is that women are made to feel that they deserve such treatment, because of inadequacies in their own intelligence and/or education."

Lakoff indicates that women's language has at least the following features: 1) They have more color terms than men (lexical difference) and some adjectives are neutral as to sex of speaker, such as great, terrific, cool, and neat; while adorable, charming, sweet, lovely and divine are used by women only. 2) They use rising intonation at the end of a sentence more frequently than men as well as more tag-questions (syntactic difference); that is, women are generally less assertive and confident than men.

In this paper, we simply had half of the cases recorded by males and half by females, asked our subjects to evaluate the speakers (sex differences not being mentioned during the attitude survey) on a seven-point semantic differential scales (as shown in Section 3.1), and then used statistics to make inferences. 


\section{Literature review}

\subsection{Languages in Taiwan}

In Taiwan, approximately $80 \%$ of the population is Taiwanese and the rest includes speakers of various Chinese dialects (Tse 1982: 33). However, the official language is not Taiwanese but Mandarin, which is spoken by more than 94 percent of the inhabitants (Tse 1982: 34). Through the efforts of the National Language Movement, Mandarin has become the national, the standard and the official language in Taiwan. It is the language of writing, the language of school instruction, and the language used in all official situations. People are constantly encouraged to learn Mandarin as the primary tool of communication. Besides, Tse (1983: 188) also noticed that there is a diglossic situation in the society. For bilingual speakers of both languages, Taiwanese is mainly used at home or only between interlocutors of close relationship and Mandarin is dominant in all public domains. Our observation, however, shows that Taiwanese is also used as the main communication medium in the meetings schoolmasters and parents of pupils, especially in the countryside and suburban areas.

Lin (1987) reports that Mandarin is the "high language", that enjoys higher and greater social prestige. Taiwanese has been reduced to a vernacular. However, since then, the political situation in Taiwan has changed a lot, so that the politicians who originally did not understand Taiwanese have begun to hire tutors to teach them the vernacular language, Taiwanese. In their Mandarin speeches on television, they like to insert one or two Taiwanese sentences to show they are close to the local people.

\subsection{Methods of language-attitude research}

Fasold (1984) states that methods for determining attitudes about language can be either direct or indirect. A totally direct method would require subjects to respond to a questionnaire or interview questions that simply ask their opinions about one or another language. A totally indirect method would be designed to keep the subject from knowing that her language attitudes were being investigated. He takes Cooper and Fishman's study (1974: 16-17) as an example of the indirect method of language-attitude research.

Cooper and Fishman hypothesize that attitudes towards Hebrew in Israel make it more effective as a language for scientific arguments. Arabic, on the other hand, would be more effective for conveying traditional Islamic arguments. To test the hypothesis, a group of Muslim adults who were bilingual in Arabic and Hebrew were asked to listen to four one-minute passages recorded by a fluent speaker of both languages. One passage decried the evils of tobacco and gave scientific evidence in support of that position. It was recorded once in each language. The other passage, also recorded once in each language, argued against the use of liquor, and used traditional Islamic arguments for support. The respondents were divided into two groups, one of which listened to the tobacco passage in Hebrew and the liquor passage in Arabic, and the other group listened to the reverse 
combination. Respondents were then asked if they would support increased taxes on tobacco or liquor to discourage their use.

The differences were dramatic. The respondents who had heard the scientific tobacco passage in Hebrew said they supported the tax on tobacco by a two-to-one ratio over those who had heard the same kind of argument in Arabic. The reverse results were obtained in the case of the traditional arguments against liquor; in comparison to those who heard it in Hebrew, twice as many of the respondents who heard the argument in Arabic said they supported the tax increase. The hypothesis appeared to be supported, but the subjects had no idea at all that their language attitudes were being investigated. Their attention had been diverted to the issues of the evils of tobacco and liquor (cited in Fasold 1984).

One serious flaw with Cooper and Fishman is that it is possible that even before the experiment, the respondents who listened to the scientific tobacco passage in Hebrew and the traditional liquor argument in Arabic (called Group I) held attitudes toward tobacco and liquor different from those of the other group, who listened to the scientific tobacco passage in Arabic and the traditional liquor argument in Hebrew (called Group II). If they had had four different groups to test their hypothesis, they could have had half of Group I listen to the scientific tobacco passage in Hebrew first and then to the traditional liquor passage in Hebrew (instead of Arabic), the other half of Group I in the reverse order, and they could have had half of Group II listen to the scientific tobacco passage in Arabic first and then to the traditional liquor passage in Arabic (instead of Hebrew), the other half of Group II in the reverse order. If they would have had the result that Group I got a significantly higher number of subjects who support the tax increase in tobacco than those who support the tax increase in liquor and that Group II got a significantly higher number of subjects who support the tax increase in liquor than those who support the tax increase in tobacco, then their hypothesis would really have been supported.

\subsection{Code-mixing: Code-borrowing vs code-switching}

Code-mixing happens where pieces of one language are used while a speaker is basically using another language. The language 'pieces' taken from another language are often words, but they can also be phrases or larger units (Gumperz 1977; Parasher 1980; Hill and Hill 1980). When they are words, the phenomenon is called code-borrowing (Fasold 1984).

One criterion that is sometimes offered to distinguish switching from mixing is that the grammar of the clause determines the language. By this criterion, if a person uses a word or a phrase from another language, he has mixed, not switched. But if one clause has the grammatical structure of one language and the next is constructed according to the grammar of another, a switch has occurred (Fasold 1984: 182).

\subsection{Dimensions of evaluation}

Lin (1987) indicates that there are three dimensions to evaluate language attitude: 
the dimension of personal integrity, that of social status, and that of affiliation or solidarity. The dimension of personal integrity includes persuasion, authority, and trustworthiness. That of social status is mainly perceived in the light of education and occupation. The speakers of the "high form" are always perceived to be more educated, more job-suitable, more intelligent, and even more wealthy, which means they have more socioeconomic status. The dimension of affiliation and/or solidarity is similar to that of likability or social attractiveness. In the dimensions of personal integrity and social status, Lin does not mention any other work; it seems that they were introduced by her. She devised three 6-point semantic differential questions for the dimension of personal integrity, another 3 for the dimension of social status, and 2 for the dimension of affiliation for her subjects to check and then she got the sum of each dimension of each subject so that the highest possible sum for the dimension of personal integrity is 18 , that for the dimension of social status is 18 too and that for the dimension of affiliation is 12. She then did an Analysis of Variance (ANOVA) to get the result that Mandarin is evaluated as possessing higher personal integrity and higher social status than Taiwanese and Taiwanese Mandarin (Mandarin with heavy Taiwanese accent). However for the dimension of affiliation, the three languages are not significantly different from each other.

One great flaw with Lin's study is that she subjectively groups the three adjectives trustworthy, persuasive, and authoritative in the dimension of personal integrity; three other attributes highly educated or not, white-collared or blue-collared, of high social status or low social status in the dimension of social status; and then easy to get along with or not, friendly or not in the dimension of affiliation. A second serious flaw is that she does not report the standard deviation with the mean of each group. The applicability of ANOVA depends on the assumption that the variance, which is the square of the standard deviation, must be homogeneous. She does not mention that she has done the test of the homogeneity of variances before she has ANOVA done, either. The third defect in her study is that the number of subjects in the contrastive groups is not equal. If the numbers are not greatly different from each other, ANOVA does not bias the results seriously; however, again the homogeneity of variances can bias the results. The fourth flaw is that if some subjects are neutral in their attitude toward the speaker, they must be either positively or negatively biased; thus, experimental errors are greater.

In our study, we used 7-point semantic differential scales instead of 6-point ones. We did not subjectively put some variables together; instead we used factor analysis to group different evaluative adjectives; by nature, factor analysis is used to reduce the evaluative variables. We also list the standard deviation under the means of the groups to compare; readers can test the homogeneity of variances themselves. Of course, we have taken this into consideration in our study.

\section{Study I}

\subsection{Method, data, and procedure}

We used a modified matched guise method (Lambert et al. 1960; Lambert 1967; d'Anglejan and Tucker 1973; El-Dash and Tucker 1975; Wolck 1973; Shuy, Bavatz, and Wolfram 1969) in studying the university students'attitude toward different kinds 
of code mixing. We don't call it code-switching because the Mandarin Chinese syntactic structure was used, only words or phrases in Taiwanese, English, and Japanese were inserted in the Mandarin Chinese syntax.

First, we asked 4 persons, 2 males and 2 females, aged from 21 to 39 years old, to speak into tape recorders, each in four kinds of codes: pure Mandarin (M), Mandarin plus Japanese $(M+J)$, Mandarin plus English $(M+E)$, and Mandarin plus Taiwanese $(\mathrm{M}+\mathrm{T})$. Therefore, there are altogether 16 cases. They spoke into four tapes: the order of speakers A (female - 37 years old), B (male - 39), C (female - 34), and D (male - 21)) and the order of codes are listed as follows.

Tape I: $M(A), M+E(B), M+T(C), M+J(D)$

Tape II: $M+J(A), M(B), M+E(C), M+T(D)$

Tape III: $M+E(A), M+T(B), M+J(C), M(D)$

Tape IV: $M+J(B), M(C), M+E(D), M+T(A)$

The four speakers were not equally good in Mandarin, Taiwanese, Japanese, and English. Only speaker A was good at the four languages. Speaker $\mathrm{C}$ was good at only Mandarin and Taiwanese. Speakers B and D were good at Mandarin, English, and Taiwanese. Before the recording task, speaker A tutored speakers B, C, and D to pronounce certain words, nouns only, in Japanese well. She also tutored speaker $\mathrm{C}$ to pronounce certain words in English well. All the four speakers spoke into the tape recorders as if they were talking to an inquirer in a live situation. Though they are not fluent speakers of English and/or Japanese, they reflect the phenomenon in Taiwan because in Taiwan those who switch codes freely are not necessarily good speakers of the codes they use.

We distributed the survey paper with seven-point semantic differential scales (Osgood, Suci, and Tannenbaum 1957) to 39 university students. They were asked to check (V) at the appropriate place after listening to each of the speakers from Tape I to Tape IV in the aforementioned order. After they listened to speaker (A) of Tape I, they checked the eleven items under case 1 , and then they listened to speaker (B) and then checked the eleven items under case 2, and so on. The eleven items are

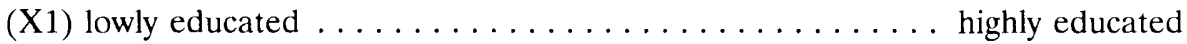

(X2) extremely untrustworthy $\ldots \ldots \ldots \ldots \ldots \ldots \ldots$ extremely trustworthy

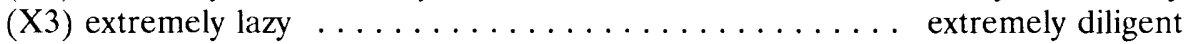

(X4) extremely unfriendly $\ldots \ldots \ldots \ldots \ldots \ldots \ldots \ldots$ extremely friendly

(X5) extremely unauthoritative $\ldots \ldots \ldots \ldots \ldots \ldots$ extremely authoritative

(X6) extremely unhumorous $\ldots \ldots \ldots \ldots \ldots \ldots \ldots$ extremely humorous

(X7) manual worker ................... intellectual worker

(X8) extremely socially unattractive $\ldots \ldots \ldots \ldots$ extremely socially attractive

(X9) extremely unwise $\ldots \ldots \ldots \ldots \ldots \ldots \ldots \ldots \ldots \ldots \ldots \ldots \ldots \ldots$ extremely wise

(X10) extremely uncandid $\ldots \ldots \ldots \ldots \ldots \ldots \ldots \ldots$ extremely candid

(X11) extremely unfond of showing off ....... extremely fond of showing off

They were told that there were sixteen speakers. All the speakers told the listeners how to get somewhere, for example, the post-office, the bank, the restaurant; in other words, they talked on a neutral topic. The message in 
Taiwanese, English, and Japanese were repeated in Mandarin immediated after code-switching to make sure the inaudible enquirer understood. By listening to the tape, the undergraduates knew that the speakers were responding to questions asking for directions.

\subsection{Statistic analysis}

After we collected the 39 pieces of paper, we first input the data into the statistical package of SAS (Statistical Analysis System), and then we got the variances of the 11 items and the total variances of the sum of the 11 items and then used the formula for Cronbach-alpha reliability coefficient (Cronbach 1951) to get the coefficient of 0.887 ; it is high. Therefore we went on doing factor analysis. After reviewing the eleven eigenvalues, we decided to retain 3 factors, because only 3 eigenvalues - 5.30, 1.31, and 1.03 - were bigger than 1 (the total of the eigenvalues is 11 , which is also the number of variables). The 3 factors explained $69.4 \%$ of all variances. ${ }^{2}$ After extracting the 3 factors, we used both the orthogonal and the optimal rotation method to calculate the factor pattern. The factor loads of factors because of the orthogonal and the optimal rotation method are listed below.

Table 1: The factor loads of the eleven variables in three factors (Varimax rotation--orthogonal rotation)

\section{FACTOR1}

$\begin{array}{llll}\text { X4 } & 0.78587 & 0.23311 & 0.23590 \\ \text { X8 } & 0.78189 & 0.07026 & 0.35346 \\ \text { X10 } & 0.77980 & 0.24235 & 0.04707 \\ \text { X3 } & 0.67597 & 0.51587 & -0.01932 \\ \text { X2 } & 0.63724 & 0.58699 & -0.08695 \\ \text { X7 } & 0.06548 & 0.85615 & 0.2270633 \\ \text { X1 } & 0.14491 & 0.82475 & 0.15230 \\ \text { X9 } & 0.38994 & 0.66108 & 0.20498 \\ \text { X5 } & 0.39524 & 0.54447 & 0.02698 \\ \text { X11 } & 0.01480 & 0.28586 & 0.79609 \\ \text { X6 } & 0.50435 & 0.02346 & 0.66912\end{array}$

\section{FACTOR3}

FACTOR2

Proportion

$29.9 \%$

$26.9 \%$

$12.6 \%$ 
Table 2: $\quad$ The factor loads of the eleven variables in three factors (Optimal rotation)

\section{FACTOR1}

0.81385

0.80151

0.79456

0.63721

0.58575

$-0.12188$

$-0.02225$

0.27553

0.31979

$-0.10754$

0.49323
FACTOR2

-0.13590
0.06129
0.04256
0.38395
0.47275
0.89449
0.84353
0.60369
0.48391
0.27277
-0.12809

FACTOR3
0.26445
$-0.05884$
0.13344
$-0.13248$
$-0.20157$
0.16711
0.08377
0.11973
$-0.05452$
0.79044
0.62144

\section{$\begin{array}{llll}\text { Proportion } & 28.5 \% & 23.6 \% & 11 \%\end{array}$}

According to the orthogonal rotation method, we put the variances with factor pattern value bigger than 0.5 together as a group, and find that variable number $\mathrm{X} 4$ (friendly or not), X8 (socially attractive or not), X10 (candid or not), X3 (diligent or not), X2 (trustworthy or not), and X6 (humorous or not) are the main elements of factor I; therefore, we name Factor I 'Human Relationship factor'. X3 (diligent or not), X2 (trustworthy or not), X7 (employment - manual jobs or intellectual jobs), X1 (highly educated or not), X9 (wise or not), and X5 (authoritative or not) are the main elements of factor II; therefore, we name it 'Power Factor'. Variables X11 (fond of showing off or not) and X6 (humorous or not) are the main elements of factor III; therefore we name it 'Wit Factor'. X3 (diligent or not) and X2 (trustworthy or not) belong to both factor I - human relationship factor, and factor II - power factor; they belong more to factor I than to factor II. X6 belongs more to factor III than to factor I.

According to the optimal rotation method, we put the variances with factor pattern value bigger than 0.48 together as a group, and find that variable number X8 (socially attractive or not), X10 (candid or not), X4 (friendly or not), X3 (diligent or not), X2 (trustworthy or not) and X6 (humorous or not) are the main elements of factor I; therefore, we name Factor I 'Human Relationship Factor'. Variables X7 (employment - manual jobs or intellectual jobs), X1 (highly educated or not), X9 (wise or not), and X5 (authoritative or not) are the main elements of factor II; therefore, we name it 'Power Factor'. Variables X11 (fond of showing off or not) and X6 (humorous or not) are the main elements of factor III; therefore we name it 'Wit Factor'. X6 is more of the Wit Factor than of the Human Relationship Factor. From what is mentioned above we know that the optimal rotation method makes better differentiation between the three factors, because variables $\mathrm{X} 3$ and $\mathrm{X} 2$ do not belong to two factors any longer. However, variable $\mathrm{X} 2$ 's load in Factor II is 0.47275 , which is close to the boundary of 0.48 . Since the 
optimal rotation method makes better demarcation of factors, we adopt it. However, the explained proportion of variances becomes $63.1 \%$, instead of $69.4 \%$. The advantage of adopting the varimax rotation method is that the explained proportion of variances will not change after rotation ${ }^{3}$.

Lin (1987) indicates that the evaluative dimensions can be of personal integrity, social status, and affiliation. It seems that what she says is not statistically proved. The factor analysis shows that the qualities of being diligent and trustworthy are closely related with the human relationship factor or Lin's dimension of affiliation. Maybe we can make a tentative conclusion here that Chinese people like diligent and trustworthy people; therefore, being diligent, being trustworthy, being candid, being friendly, and being socially attractive are grouped together to form the human relation factor or factor of affiliation and solidarity.

Every subject in each of the 16 cases got three factor scores according to the following standardized scoring coefficients computed via optimal rotation method.

Table 3: $\quad$ Standardized Scoring Coefficients

FACTOR 1

$\begin{array}{llll}\text { X8 } & 0.26788 & -0.12898 & 0.17842 \\ \text { X10 } & 0.27115 & -0.02934 & -0.10720 \\ \text { X4 } & 0.25728 & -0.04750 & 0.05797 \\ \text { X3 } & 0.19719 & 0.11790 & -0.17742 \\ \text { X2 } & 0.17799 & 0.16168 & -0.23787 \\ \text { X7 } & -0.11680 & 0.36285 & 0.09896 \\ \text { X1 } & -0.07380 & 0.33976 & 0.02431 \\ \text { X9 } & 0.04195 & 0.21876 & 0.04878 \\ \text { X5 } & 0.07722 & 0.17689 & -0.09559 \\ \text { X11 } & -0.10892 & 0.07322 & 0.66417 \\ \text { X6 } & 0.13479 & -0.12326 & 0.50321\end{array}$

Since the factor scores are standardized; the grand means of Factor 1 to Factor 3 are all zero, and the SD (standard deviation) for each of the three factors is 1 . Then we count the means and standard deviations of the four speakers in four different codes. Tables 4 to 6 are the mean scores and standard deviations of the three factors.

${ }^{3}$ We thank Prof Deng-Yuan Huang of Department of Statistics, Feng Chia University in Taichung for his valuable comments on factor analysis. One of us, Chao-chih Liao took courses Nonparametric Statistics and Multivariate Statistics with him. 
Table 4: Human Relationship Factor--Means and (SD)

\begin{tabular}{|c|c|c|c|c|c|}
\hline & Mandarin & $M+J$ & $M+E$ & $\ddot{M}+\mathrm{T}$ & $\begin{array}{r}\text { Speaker } \\
\text { Mean }\end{array}$ \\
\hline Speaker A (6F) & $\begin{array}{l}-0.0895 \\
(0.96)\end{array}$ & $\begin{array}{l}-0.080 \\
(1.07)\end{array}$ & $\begin{array}{l}-0.0325 \\
(0.97)\end{array}$ & $\begin{array}{l}0.347 \\
(1.01)\end{array}$ & $\begin{array}{l}0.036 \\
(1.01)\end{array}$ \\
\hline Speaker B (M) & $\begin{array}{l}-0.524 \\
(0.96)\end{array}$ & $\begin{array}{l}-0.269 \\
(0.81)\end{array}$ & $\begin{array}{r}-0.089 \\
(0.91)\end{array}$ & $\begin{array}{l}-0.061 \\
(0.94)\end{array}$ & $\begin{array}{r}-0.236 \\
(0.92)\end{array}$ \\
\hline Speaker C $(F)$ & $\begin{array}{l}0.027 \\
(0.93)\end{array}$ & $\begin{array}{l}0.075 \\
(0.94)\end{array}$ & $\begin{array}{r}-0.278 \\
(0.90)\end{array}$ & $\begin{array}{l}0.744 \\
(0.94)\end{array}$ & $\begin{array}{l}0.142 \\
(0.99)\end{array}$ \\
\hline Speaker D (M) & $\begin{array}{l}-0.286 \\
(1.16)\end{array}$ & $\begin{array}{l}-0.225 \\
(1.01)\end{array}$ & $\begin{array}{l}0.163 \\
(0.79)\end{array}$ & $\begin{array}{l}0.577 \\
(0.99)\end{array}$ & $\begin{array}{l}0.057 \\
(1.05)\end{array}$ \\
\hline Code mean & $\begin{array}{l}-0.218 \\
(1.02)\end{array}$ & $\begin{array}{l}-0.125 \\
(0.96)\end{array}$ & $\begin{array}{l}-0.059 \\
(0.90)\end{array}$ & $\begin{array}{l}0.402 \\
(1.01)\end{array}$ & $\begin{array}{l}0(\mathrm{Gr} \\
\text { Mean }) \\
(1)\end{array}$ \\
\hline
\end{tabular}

Table 5: $\quad$ Power Factor--Means and (SD)

\begin{tabular}{|c|c|c|c|c|c|}
\hline & Mandarin & $M+J$ & $M+E$ & $M+T$ & $\begin{array}{r}\text { Speaker } \\
\text { Mean }\end{array}$ \\
\hline Speaker A (F) & $\begin{array}{l}0.624 \\
(0.98)\end{array}$ & $\begin{array}{l}-0.565 \\
(0.87)\end{array}$ & $\begin{array}{l}1.120 \\
(0.64)\end{array}$ & $\begin{array}{l}0.198 \\
(0.73)\end{array}$ & $\begin{array}{l}0.337 \\
(1.03)\end{array}$ \\
\hline Speaker B (M) & $\begin{array}{l}-0.234 \\
(0.95)\end{array}$ & $\begin{array}{l}-0.183 \\
(0.81)\end{array}$ & $\begin{array}{l}-0.360 \\
(0.95)\end{array}$ & $\begin{array}{l}-0.665 \\
(0.82)\end{array}$ & $\begin{array}{l}-0.358 \\
(0.89)\end{array}$ \\
\hline Speaker C (F) & $\begin{array}{l}0.397 \\
(0.82)\end{array}$ & $\begin{array}{l}-0.572 \\
(0.73)\end{array}$ & $\begin{array}{l}0.403 \\
(0.82)\end{array}$ & $\begin{array}{l}-0.607 \\
(1.24)\end{array}$ & $\begin{array}{l}-0.255 \\
(1.02)\end{array}$ \\
\hline Speaker D (M) & $\begin{array}{c}0.486 \\
(0.88)\end{array}$ & $\begin{array}{l}-0.023 \\
(0.82)\end{array}$ & $\begin{array}{r}0.677 \\
(0.72)\end{array}$ & $\begin{array}{l}0.137 \\
(0.84)\end{array}$ & $\begin{array}{l}0.276 \\
(0.87)\end{array}$ \\
\hline Code mean & $\begin{array}{l}0.120 \\
(1.02)\end{array}$ & -0.309 & 0.412 & $\begin{array}{l}-0.223 \\
(1.01)\end{array}$ & $\begin{array}{l}0(\mathrm{Gr} \\
\text { Mean }) \\
(1)\end{array}$ \\
\hline
\end{tabular}


Table 6: Wit Factor--Means and (SD)

\begin{tabular}{|c|c|c|c|c|c|}
\hline & Mandarin & $M+J$ & $M+E$ & $M+T$ & $\begin{array}{l}\text { Speaker } \\
\text { Mean }\end{array}$ \\
\hline Speaker A (F) & $\begin{array}{l}-1.043 \\
(0.85)\end{array}$ & $\begin{array}{l}-0.358 \\
(0.86)\end{array}$ & $\begin{array}{l}0.331 \\
(0.85)\end{array}$ & $\begin{array}{l}0.015 \\
(0.84)\end{array}$ & $\begin{array}{c}-0.249 \\
(0.97)\end{array}$ \\
\hline Speaker B (M) & $\begin{array}{r}-0.343 \\
(0.81)\end{array}$ & $\begin{array}{l}-0.338 \\
(0.82)\end{array}$ & $\begin{array}{l}0.553 \\
(1.22)\end{array}$ & $\begin{array}{c}-0.214 \\
(0.80)\end{array}$ & $\begin{array}{c}-0.121 \\
(1.01)\end{array}$ \\
\hline Speaker C (F) & $\begin{array}{c}-0.648 \\
(0.89)\end{array}$ & $\begin{array}{c}-0.229 \\
(0.88)\end{array}$ & $\begin{array}{l}0.344 \\
(0.67)\end{array}$ & $\begin{array}{l}0.563 \\
(1.07)\end{array}$ & $\begin{array}{l}0.001 \\
(1.00)\end{array}$ \\
\hline Speaker D (M) & $\begin{array}{r}-0.220 \\
(0.79)\end{array}$ & $\begin{array}{l}0.267 \\
(1.13)\end{array}$ & $\begin{array}{l}0.488 \\
(0.60)\end{array}$ & $\begin{array}{l}0.885 \\
(0.79)\end{array}$ & $\begin{array}{c}0.369 \\
(0.919)\end{array}$ \\
\hline Code mean & $\begin{array}{r}-0.533 \\
(0.88)\end{array}$ & $\begin{array}{r}-0.159 \\
(0.98)\end{array}$ & $\begin{array}{l}0.46 \\
(0.87)\end{array}$ & $\begin{array}{l}0.23 \\
(0.98)\end{array}$ & $\begin{array}{l}0(\mathrm{Gr} \\
\text { Mean) } \\
(1)\end{array}$ \\
\hline
\end{tabular}

From Tables 4 to 6 , it is found that twelve cells in each table receive positive signs and the other twelve, except for the bottom right cell, receive negative signs. This is because the grand mean for each table is zero. From the 3 tables, it is also found that the means are different because of the speaker difference and code difference. Since this is a within-subject design, we did a two-way Analysis of Variances (ANOVA) for repeated measures to the data. Again because this is a within-subject design, the error terms are different for each effect to be discussed.

Table 7: $\quad$ Human relationship factor

$\begin{array}{llllll}\text { Source } & \text { DF } & \text { Anova SS } & \text { Mean Square } & \text { F Value } & \operatorname{Pr}>\text { F } \\ \text { SUBJECT } & 38 & 265.7412913 & 6.9931919 & & \\ \text { SPEAKER } & 3 & 12.53249146 & 4.17749715 & 7.27 & 0.0002 \\ \begin{array}{l}\text { Error term for } \\ \quad 114\end{array} & 65.4902020 & 0.5744755 & & \\ \begin{array}{l}\text { Speker effect } \\ \text { CODE }\end{array} & 3 & 35.58928524 & 11.86309508 & 17.67 & 0.0001 \\ \begin{array}{l}\text { Error term for } \\ \quad \text { Code effect }\end{array} & 114 & 76.5448766 & 0.6714463 & & \\ \begin{array}{l}\text { SPEAKER*CODE } \\ \text { Error term for }\end{array} & 9 & 15.21807207 & 1.69089690 & 3.81 & 0.0001 \\ \begin{array}{l}\text { Speaker and Code } \\ \text { interaction }\end{array} & 151.8841107 & 0.4441056 & & \\ \begin{array}{l}\text { Total } \\ \text { Total }\end{array} & & & & & \\ \end{array}$


Table 8: $\quad$ Power effect

\begin{tabular}{|c|c|c|c|c|c|}
\hline Source & $\mathrm{DF}$ & Anova SS & Mean Square & F Value & $\operatorname{Pr}>F$ \\
\hline Individual differ. & 38 & 180.1225005 & 4.7400658 & & \\
\hline SPEAKER & 3 & 59.66151163 & 19.88717054 & 42.36 & 0.0001 \\
\hline $\begin{array}{l}\text { Error term for } \\
\text { Speaker effect }\end{array}$ & 114 & 53.5154635 & 0.4694339 & & \\
\hline CODE & 3 & 51.39584389 & 17.13194796 & 22.71 & 0.0001 \\
\hline $\begin{array}{l}\text { Error term of } \\
\text { Code effect }\end{array}$ & 114 & 85.9839276 & 0.7542450 & & \\
\hline SPEAKER*CODE & 9 & 36.04423116 & 4.00491457 & 8.76 & 0.0001 \\
\hline $\begin{array}{l}\text { Error term for } \\
\text { Speker and code } \\
\text { interaction }\end{array}$ & 342 & 156.2765881 & 0.4569491 & & \\
\hline Total & 623 & 623.0000663 & & & \\
\hline
\end{tabular}

Table 9: Wit factor

\begin{tabular}{|c|c|c|c|c|c|}
\hline Source & DF & Anova SS & Mean Square & F Value & $\operatorname{Pr}>F$ \\
\hline Individual differ. & 38 & 122.1187534 & 3.2136514 & & \\
\hline SPEAKER & 3 & 33.14914518 & 11.04971506 & 19.91 & 0.0001 \\
\hline $\begin{array}{l}\text { Error term for } \\
\text { Speaker effect }\end{array}$ & 114 & 63.2584521 & 0.5548987 & & \\
\hline CODE & 3 & 89.98755074 & 29.99585025 & 38.57 & 0.0001 \\
\hline $\begin{array}{l}\text { Error term for } \\
\text { Code effect }\end{array}$ & 114 & 88.6546701 & 0.7776725 & & \\
\hline SPEAKER *CODE & 9 & 20.10367599 & 2.23374178 & 3.71 & 0.0002 \\
\hline $\begin{array}{l}\text { Error term for } \\
\text { Speaker and code } \\
\text { interaction }\end{array}$ & 342 & 205.7277954 & 0.6015433 & & \\
\hline Total & 623 & 623.0000430 & & & \\
\hline
\end{tabular}

From Tables 7 to 9, we find that different speakers and different codes have significantly important effects on the subjects' selection of the three factors. Furthermore, there are significant interaction effects between speakers and codes.

\subsection{Code effect}

Our main interest is the code effect and the gender effect, not the speaker effect, because when different speakers have special effects based on their voice quality or loudness, it would be very difficult to draw a conclusion, nor is it necessary. Now we did a posteriori comparisons to the code effect by applying the Tukey method 
(Lin 1985) to each of the 6 possible pairs of comparisons and found that in factor I (human relationship factor), the mixing of Mandarin plus Taiwanese got a significantly higher mean than the other three (pure Mandarin or the mixings of Mandarin and Japanese or Mandarin and English). As for the other 3, the means are not significantly different from each other.

$$
\begin{aligned}
& (\mathrm{M}+\mathrm{T})-(\mathrm{M})=9.45[\mathrm{q} .95(4,152)=3.63 ; \mathrm{q} .99(4,152)=4.40] \\
& (\mathrm{M}+\mathrm{T})-(\mathrm{M}+\mathrm{J})=8.03 \text { (s.) } \\
& (\mathrm{M}+\mathrm{T})-(\mathrm{M}+\mathrm{E})=7.03 \text { (s.)* } \\
& (\mathrm{M}+\mathrm{E})-(\mathrm{M}+\mathrm{J})=1.01 \text { (n.s.) } \\
& (\mathrm{M}+\mathrm{E})-(\mathrm{M})=2.4 \text { (n.s.) } \\
& (\mathrm{M}+\mathrm{J})-(\mathrm{M})=1.41 \text { (n.s.) }
\end{aligned}
$$

It is a universal idea that low language serves the unifying and separating functions. The result of the human relationship factor analysis seems to support this. The low language, Taiwanese, enjoys a significantly higher mean than the other three guises.

In factor II (Power factor), the Tukey method of a posteriori comparisons shows that the mixing of Mandarin and English got a significantly higher mean than the other three, (pure Mandarin, Mandarin plus Taiwanese, and Mandarin plus Japanese). Pure Mandarin also got a significantly higher mean than the mixing of Mandarin and Taiwanese or the mixing of Mandarin and Japanese. Concerning the mixing of Mandarin and Taiwanese as well as that of Mandarin and Japanese, there is no significant difference in means between them.

$$
\begin{aligned}
& (M+E)-(M)=4.20(p<.05) \\
& (M+E)-(M+J)=10.37(p<.01) \\
& (M+E)-(M+T)=9.14(p<.01) 52 \\
& (M)-(M+J)=6.17(p<.01) \\
& (M)-(M+T)=4.9(p<.01) \\
& (M+T)-(M+J)=1.24 \text { (n. s. })
\end{aligned}
$$

It is also a universal idea that speakers using the high guise would be rated higher in intelligence, occupational status. Concerning the two main languages, Mandarin and Taiwanese. Mandarin is significantly higher in the power factor than the low language Taiwanese. When the international language English is taken into account, it is the foreign language which enjoys a higher rate in the speaker's being wise, intelligent, highly educated, and engaged in intellectual vocations. Though all jobs are equal theoretically, intellectual vocations are generally occupied by the highly 
educated and manual ones by the lowly educated. What is noteworthy is the status rating of the mixing of Mandarin and Japanese, the second most widely learned foreign language in Taiwan. It is rated as low as the low language, Taiwanese, in Taiwan. As we have stated at the beginning of this paper, Japanese was the national and the standard language between 1895 and 1945. It seems that the mixing of Mandarin and Japanese reminds one of the incommunicable, old-fashioned, stubborn, unpopular old people, though Chinese people are respected for their filial piety.

The result is the same as Carranza and Ryan (1975: 99) and El-Dash and Tucker (1975). Carranza and Ryan found in their attitude research with Mexican Americans, that both Anglo- and Mexican Americans rated English higher than Spanish on status scales. El-Dash and Tucker (1975: 46) cited three studies, including their own, in which superposed language varieties English were preferred over mother tongues, according to the results of attitude research. Our study, however, shows that not all superposed language varieties are preferred. It may be a universal phenomenon that if the superposed language variety is English, instead of Japanese or other languages, then it is preferred.

As for Factor III (the Wit factor), the mixing of Mandarin plus English got a significantly higher mean than the mixing of Mandarin plus Japanese and pure Mandarin. The mixing of Mandarin plus Taiwanese got significantly higher mean than pure Mandarin and the mixing of Mandarin and Japanese. The mixing of Mandarin plus English and that of Mandarin plus Taiwanese are not significantly different from each other in mean.

$$
\begin{aligned}
& (M+E)-(M)=14.14(p<.01) \\
& (M+E)-(M+J)=8.84(p<.01) \\
& (M+E)-(M+T)=3.37(\text { n. s. }) \\
& (M+T)-(M)=10.76(p<.01) \\
& (M+T)-(M+J)=5.47(p<.01) \\
& (M+J)-(M)=5.30(p<.01)
\end{aligned}
$$

Briefly, to show that $\mathrm{s}$ /he is candid, friendly, socially attractive, diligent, and trustworthy, the speaker has to mix Mandarin and Taiwanese. To show s/he is wise, authoritative, highly educated, and engaged in intellectual jobs, it is suggested that the speaker uses Mandarin plus English, or as the second priority speaks pure Mandarin. To show off or to reach humorous effect, it is suggested that the speaker speaks Mandarin plus English, or as a second priority Mandarin plus Taiwanese or as the third priority Mandarin plus Japanese.

Brown and Yule (1983) indicate that it is usually possible to determine from a speaker's voice his or her age, approximate age and educational status, as well as some aspects of state of health and personality (p. 10). However, it seems that their proposal is not quantitatively verified. In this study, the four speakers were not equally well-educated. Speaker $\mathrm{A}$ is a university instructor, a prospective doctorate 
degree holder; Speaker B a junior high school teacher, a bachelor degree holder; Speaker C, a housewife, finished senior high school education; and Speaker D, an undergraduate, a medical school junior. From Table 5 (means and SD's for the power factor), it is found that the order of speaker means from the highest to the lowest is Speaker A, Speaker D, Speaker C, and Speaker B (instead of A, B, D, and C).

\subsection{Gender effect}

Table 4-1: Human Relationship Factor--Means and (SD) by Gender

\begin{tabular}{|c|c|c|c|c|c|}
\hline & Mandarin & $\mathrm{M}+\mathrm{J}$ & $M+E$ & $\mathrm{M}+\mathrm{T}$ & $\begin{array}{l}\text { Gender } \\
\text { Mean }\end{array}$ \\
\hline Male speaker & $\begin{array}{l}-0.4048 \\
(1.06)\end{array}$ & $\begin{array}{l}-0.247 \\
(0.91)\end{array}$ & $\begin{array}{l}0.0371 \\
(0.86)\end{array}$ & $\begin{array}{l}0.258 \\
(1.01)\end{array}$ & $\begin{array}{l}-0.089 \\
(0.99)\end{array}$ \\
\hline Femal speaker & $\begin{array}{c}\cdots \\
-0.031 \\
(0.96)\end{array}$ & $\begin{array}{l}\cdots \\
-0.002 \\
(0.81)\end{array}$ & $\begin{array}{l}\cdots \ldots \\
-0.155 \\
(0.91)\end{array}$ & $\begin{array}{l}\cdots \\
0.546 \\
(0.94)\end{array}$ & $\begin{array}{l}0.089 \\
(1.00)\end{array}$ \\
\hline Code mean & $\begin{array}{c}\cdots \\
-0.218 \\
(1.02)\end{array}$ & $\begin{array}{l}\cdots \\
-0.125 \\
(0.96)\end{array}$ & $\begin{array}{l}\ldots \\
-0.059 \\
(0.90)\end{array}$ & $\begin{array}{l}0.402 \\
(1.01)\end{array}$ & $\begin{array}{l}\cdots \\
0 \\
(1)\end{array}$ \\
\hline
\end{tabular}

Table 4-2: Power Factor--Means and the (SD) by Gender

\begin{tabular}{|c|c|c|c|c|c|}
\hline & Mandarin & $\mathrm{M}+\mathrm{J}$ & $M+E$ & $\mathrm{M}+\mathrm{T}$ & $\begin{array}{r}\text { Gender } \\
\text { Mean }\end{array}$ \\
\hline Male speaker & $\begin{array}{l}0.082 \\
(0.96)\end{array}$ & $\begin{array}{l}-0.114 \\
(0.82)\end{array}$ & $\begin{array}{l}0.135 \\
(0.97)\end{array}$ & $\begin{array}{l}-0.268 \\
(0.94)\end{array}$ & $\begin{array}{l}-0.041 \\
(0.93)\end{array}$ \\
\hline Female speaker & $\begin{array}{l}0.158 \\
(1.09)\end{array}$ & $\begin{array}{c}-0.504 \\
(0.85)\end{array}$ & $\begin{array}{l}\ldots .6 \\
0.689 \\
(0.84)\end{array}$ & $\begin{array}{l}-0.177 \\
(1.08)\end{array}$ & $\begin{array}{l}0.041 \\
(1.06)\end{array}$ \\
\hline Code mean & $\begin{array}{l}0.120 \\
(1.02)\end{array}$ & $\begin{array}{l}-0.309 \\
(0.85)\end{array}$ & $\begin{array}{l}\cdots .412 \\
(0.94)\end{array}$ & $\begin{array}{l}\cdots \\
-0.223 \\
(1.01)\end{array}$ & $\begin{array}{l}0 \\
(1)\end{array}$ \\
\hline
\end{tabular}


Table 4-3: Wit Factor--Means and the (SD) by Gender

\begin{tabular}{|c|c|c|c|c|c|}
\hline & Mandarin & $M+J$ & $M+E$ & $\mathrm{M}+\mathrm{T}$ & $\begin{array}{r}\text { Gender } \\
\text { Mean }\end{array}$ \\
\hline Male speaker & $\begin{array}{l}-0.270 \\
(0.80)\end{array}$ & $\begin{array}{l}-0.012 \\
(1.04)\end{array}$ & $\begin{array}{l}0.512 \\
(0.99)\end{array}$ & $\begin{array}{l}0.266 \\
(0.97)\end{array}$ & $\begin{array}{l}0.124 \\
(0.99)\end{array}$ \\
\hline Female speaker & $\begin{array}{c}\cdots \\
-0.796 \\
(0.88)\end{array}$ & $\begin{array}{l}\cdots \\
-0.306 \\
(0.90)\end{array}$ & $\begin{array}{l}\cdots \\
0.418 \\
(0.72)\end{array}$ & $\begin{array}{l}\cdots \\
0.188 \\
(0.99)\end{array}$ & $\begin{array}{l}\ldots \ldots \\
-0.124 \\
(0.99)\end{array}$ \\
\hline Code mean & $\begin{array}{l}-0.533 \\
(0.88)\end{array}$ & $\begin{array}{l}\cdots \\
-0.159 \\
(0.98)\end{array}$ & $\begin{array}{l}\cdots .46 \\
(0.87)\end{array}$ & $\begin{array}{l}0.23 \\
(0.98)\end{array}$ & $\begin{array}{l}\cdots \\
0 \\
(1)\end{array}$ \\
\hline
\end{tabular}

Table 7-1: Human relationship factor

$\begin{array}{llllll}\text { Source } & \text { DF } & \text { Anova SS } & \text { Mean Square } & \text { F Value } & \text { Pr > F } \\ \text { Individual differ. } & 38 & 265.7412913 & 6.9931919 & & \\ \text { SPEAKER SEX } & 1 & 4.96701302 & 4.96701302 & 6.57 & 0.0145 \\ \begin{array}{l}\text { Error Term for } \\ \quad 38\end{array} & 28.7276585 & 0.7559910 & & \\ \quad \text { Sex effect } & & & & & \\ \text { CODE } & 3 & 35.58928524 & 11.86309508 & 17.67 & 0.0001 \\ \quad \text { Error term for } & 114 & 76.5448766 & 0.6714463 & & \\ \quad \text { Code effect } & & & & & \\ \text { SEX*CODE } & 3 & 7.47711932 & 2.49237311 & 5.72 & \\ \text { Error term for } & 114 & 49.6690148 & 0.4356931 & & \\ \quad \text { interact. effect } & & & & & \\ \quad \text { Error } & 312 & 154.2840705 & 0.4945002 & & \\ \text { Total } & 623 & 623.0003294 & & & \end{array}$

Table 8-1: $\quad$ Power factor

$\begin{array}{llllll}\text { Source } & \text { DF } & \text { Anova SS } & \text { Mean Square } & \text { F Value } & \text { Pr > F } \\ \text { Individual differ. } & 38 & 180.1225005 & 4.7400658 & & \\ \text { SPEAKER SEX } & 1 & 1.05745722 & 1.05745722 & 2.13 & 0.1526 \\ \text { SUBJECT*SEX } & 38 & 18.8595895 & 0.4963050 & & \\ \text { CODE } & 3 & 51.39584389 & 17.13194796 & 22.71 & 0.0001 \\ \text { SUBJECT*CODE } & 114 & 85.9839276 & 0.7542450 & & \\ \text { SEX*CODE } & 3 & 17.35297939 & 5.78432646 & 9.39 & 0.0001 \\ \text { SUBJ*SEX*CODE } & 114 & 70.2551099 & 0.6162729 & & \\ \text { Error } & 312 & 197.9726584 & 0.6345278 & & \\ \text { Total } & 623 & 623.0000663 & & & \end{array}$


Table 9-1: Wit factor

$\begin{array}{llllll}\text { Source } & \text { DF } & \text { Anova SS } & \text { Mean Square } & \text { F Value } & \operatorname{Pr}>\text { F } \\ & & & & & \\ \text { SUBJECT } & 38 & 122.1187534 & 3.2136514 & & \\ \text { SPEAKER SEX } & 1 & 9.57012238 & 9.57012238 & 13.30 & 0.0008 \\ \text { SUBJECT*SEX } & 38 & 27.3388298 & 0.7194429 & & \\ \text { CODE } & 3 & 89.98755074 & 29.99585025 & 38.57 & 0.0001 \\ \text { SUBJECT*CODE } & 114 & 88.6546701 & 0.7776725 & & \\ \text { SEX*CODE } & 3 & 5.13260684 & 1.71086895 & 2.53 & 0.0609 \\ \text { SUBJ*SEX*CODE } & 114 & 77.1593306 & 0.6768362 & & \\ \text { Error } & 312 & 203.0381791 & 0.6507634 & & \\ \text { Total } & 623 & 623.0000430 & & & \end{array}$

Tables 7-1 to 9-1 are similar to Tables 7 to 9 respectively: the only difference is that the sex effect shown, not the speaker effect. From the three tables, we find that females got significantly higher means than males in the human relationship factor. The two sexes are not significantly different in means in the power factor. Males got significantly higher means than females in the wit factor.

There are significant interaction effects between the code used and gender in the human relationship and power factors.

\section{Study II}

When Ms Hsiao had her students listen to the 16 cases of the recorded directions, her students were very excited about it at the beginning, but after four or five cases she found that they were getting bored. Therefore, Study II followed to prevent the subjects from feeling bored: we had four different classes of undergraduates listen to the four tapes mentioned in Study I4. Each class listened to only four cases in one tape. All subjects participated in the study voluntarily and were excited about listening to the tapes. The procedure was the same as in Study I.

In this study, besides doing the same jobs as in Study I, subjects were asked to write out their age, their perceptions about the speakers' ages. The subjects' average age is 20.1 , with the youngest 18 and the oldest 26. Speakers A to D's actual ages are $37,39,34$, and 21 , respectively; and the subjects' perceptions about their ages are 29.34 (range of 13 to 50), 32.22 (range of 15 to 80), 30.33 (range of 15 to 60, and 24.36 (range of 15 to 48), respectively. It seems that Brown and Yule's claim (1983: 10) that a speaker's age can be determined from his/her voice is not verified. It is also possible that the quality of the tape recorder makes the difference.

After the survey papers were collected from the four classes, the data were input into SAS and the factor analysis was done.

After we collected the $35,35,35$, and 33 pieces of paper from the subjects listening to Tape I, Tape II, Tape III, and Tape IV respectively, we input the data into SAS, and then we got the variances of the 11 items and the total variances of 
the sum of the 11 items and then used the formula for Cronbach-alpha reliability coefficient (Cronbach 1951) to get the coefficient of 0.813 ; it is high (though not so high as the coefficient of the within-subject design in Study I). Therefore we went on doing factor analysis. After reviewing the eleven eigenvalues, as in Study I, we also decided to retain 3 factors, because 3 eigenvalues - 4.11, 1.68, and 1.27 - are bigger than 1 . The 3 factors explain $64.3 \%$ of all variances. After extracting the 3 factors, we use both the orthogonal and the optimal rotation method to calculate the factor pattern. The factor loads of factors resulting from the orthogonal and the optimal rotation method are listed below.

Table 10: The factor loads of the eleven variables in three factors (Varimax rotation--orthogonal rotation)

\section{FACTOR 1}

$\begin{array}{llll}\text { X4 } & 0.80890 & 0.11663 & 0.20460 \\ \text { X10 } & 0.78647 & 0.06526 & -0.00758 \\ \text { X3 } & 0.73662 & 0.31295 & -0.08411 \\ \text { X8 } & 0.69979 & -0.00179 & 0.46749 \\ \text { X2 } & 0.68769 & 0.40145 & -0.20621 \\ \text { X1 } & 0.05830 & 0.86070 & 0.05750 \\ \text { X7 } & 0.04331 & 0.76473 & 0.21990 \\ \text { X5 } & 0.24768 & 0.66633 & 0.02100 \\ \text { X9 } & 0.33095 & 0.66197 & 0.21979 \\ \text { X6 } & 0.25156 & 0.09569 & 0.82471 \\ \text { X11 } & -0.17594 & 0.22381 & 0.62052 \\ \ldots \ldots\end{array}$

\section{FACTOR2 FACTOR3}

\section{Proportion $\quad 27.7 \% \quad 23.1 \% \quad 13.4 \%$}

Table 11: The factor loads of the eleven variables in three factors (Optimal rotation)

\section{FACTOR1}

$\begin{array}{llll}\text { X10 } & 0.81466 & -0.06867 & -0.05716 \\ \text { X4 } & 0.81239 & -0.02861 & 0.15393 \\ \text { X3 } & 0.73299 & 0.20103 & -0.14523 \\ \text { X8 } & 0.69274 & -0.14452 & 0.43331 \\ \text { X2 } & 0.67937 & 0.30704 & -0.27098 \\ \text { X1 } & -0.06926 & 0.88246 & 0.00844 \\ \text { X7 } & -0.08496 & 0.77800 & 0.17920 \\ \text { X5 } & 0.16050 & 0.64897 & -0.02915 \\ \text { X9 } & 0.23120 & 0.62107 & 0.16783 \\ \text { X6 } & 0.17843 & 0.01894 & 0.81652 \\ \text { X11 } & -0.27028 & 0.23570 & 0.62751\end{array}$

\section{FACTOR3}
$-0.05716$
0.15393
$-0.14523$
0.43331
$-0.27098$
0.00844
0.17920
0.16783
0.81652
0.62751 
No matter we adopt the orthogonal rotation method or the optimal rotation method, we can put the variances with factor pattern value bigger than 0.6 together as a group, and find that variable number X10 (Candid or not), X4 (friendly or not), X8 (socially attractive or not), X3 (diligent or not) and X2 (trustworthy or not) are the main elements of factor I; therefore, we name Factor I 'Human Relationship factor'. X7 (employment - manual jobs or intellectual jobs), X1 (highly educated or not), X9 (wise or not), and X5 (authoritative or not) are the main elements of factor II; therefore, we name it 'Power Factor'. Variables X11 (fond of showing off or not) and X6 (humorous or not) are the main elements of factor III; therefore we name it 'Wit Factor'. However, the explained proportion via optimal rotation method becomes $62.2 \%$ instead of $64.3 \%$. We therefore adopt the varimax rotation method, because advantage of adopting the varimax rotation method is that the explained proportion of variances will not change after rotation and it has stronger theoretical basis than the optimal rotation method.

The two studies are reliable, because the factors extracted are the same. Again, the dimension of personal integrity as mentioned in Lin (1987) is not a separate dimension in our study, but closely related to the dimension of affiliation - or what we called human relationship factor. Now we go on analyzing the data: ANOVA is used to know the code effect on the factor scores. Tables 12 to 14 show the means of each code in each factor. Tables 15 to 17 are the summaries of ANOVA.

Table 12: Human relationship factor: The means and (the SD)

\begin{tabular}{|c|c|c|c|c|c|}
\hline & Mandarin & $\mathrm{M}+\mathrm{J}$ & $M+E$ & $\mathrm{M}+\mathrm{T}$ & $\begin{array}{r}\text { Gender } \\
\text { Mean }\end{array}$ \\
\hline Male speaker & $\begin{array}{l}-0.174 \\
(1.097)\end{array}$ & $\begin{array}{r}-0.295 \\
(0.90)\end{array}$ & $\begin{array}{l}-0.444 \\
(0.87)\end{array}$ & $\begin{array}{r}0.350 \\
(1.18)\end{array}$ & $\begin{array}{l}-0.137 \\
(1.06)\end{array}$ \\
\hline Female speaker & $\begin{array}{l}\cdots \\
0.190 \\
(0.73)\end{array}$ & $\begin{array}{l}\cdots \\
0.150 \\
(0.98)\end{array}$ & $\begin{array}{l}\ldots \ldots \\
-0.171 \\
(0.91)\end{array}$ & $\begin{array}{l}0.388 \\
(0.95)\end{array}$ & $\begin{array}{l}\ldots \ldots \\
0.137 \\
(0.92)\end{array}$ \\
\hline Code Mean & $\begin{array}{l}0.0052 \\
(0.95)\end{array}$ & $\begin{array}{c}-0.069 \\
(0.97)\end{array}$ & $\begin{array}{l}-0.3056 \\
(0.90)\end{array}$ & $\begin{array}{l}0.369 \\
(1.07)\end{array}$ & $\begin{array}{l}\cdots \\
0 \\
(1)\end{array}$ \\
\hline
\end{tabular}


Table 13: Power factor: the Means and (the SD)

\begin{tabular}{|c|c|c|c|c|c|}
\hline & Mandarin & $\mathrm{M}+\mathrm{J}$ & $M+E$ & $\mathrm{M}+\mathrm{T}$ & $\begin{array}{r}\text { Gender } \\
\text { Mean }\end{array}$ \\
\hline Male speaker & $\begin{array}{l}\ldots \ldots \\
0.251 \\
(0.96)\end{array}$ & $\begin{array}{l}0.123 \\
(0.89)\end{array}$ & $\begin{array}{l}0.33 \\
(0.80)\end{array}$ & $\begin{array}{l}-0.193 \\
(1.06)\end{array}$ & $\begin{array}{l}0.127 \\
(0.95)\end{array}$ \\
\hline Female speaker & $\begin{array}{l}-0.027 \\
(0.99)\end{array}$ & $\begin{array}{l}\cdots \\
-0.447 \\
(0.95)\end{array}$ & $\begin{array}{l}\ldots .414 \\
(1.00)\end{array}$ & $\begin{array}{l}-0.456 \\
(0.94)\end{array}$ & $\begin{array}{l}-0.127 \\
(1.03)\end{array}$ \\
\hline Code Mean & $\begin{array}{l}\ldots .114 \\
(0.99)\end{array}$ & $\begin{array}{l}\cdots \\
-0.166 \\
(0.97)\end{array}$ & $\begin{array}{l}\ldots .375 \\
(0.90)\end{array}$ & $\begin{array}{l}\ldots \ldots \\
-0.323 \\
(1.01)\end{array}$ & $\begin{array}{l}\cdots \\
0 \\
(1)\end{array}$ \\
\hline
\end{tabular}

Table 14: Wit factor

\begin{tabular}{|c|c|c|c|c|c|}
\hline & Mandarin & $\mathrm{M}+\mathrm{J}$ & $M+E$ & $\mathrm{M}+\mathrm{T}$ & $\begin{array}{l}\text { Gender } \\
\text { Mean }\end{array}$ \\
\hline Male speaker & $\begin{array}{l}-0.231 \\
(0.95)\end{array}$ & $\begin{array}{l}0.250 \\
(0.80)\end{array}$ & $\begin{array}{l}0.68 \\
(0.96)\end{array}$ & $\begin{array}{l}0.39 \\
(1.04)\end{array}$ & $\begin{array}{c}0.267 \\
(0.99)\end{array}$ \\
\hline Female speaker & $\begin{array}{l}-0.730 \\
(0.82)\end{array}$ & $\begin{array}{l}-0.472 \\
(0.75)\end{array}$ & $\begin{array}{l}-0.103 \\
(0.92)\end{array}$ & $\begin{array}{l}0.237 \\
(0.96)\end{array}$ & $\begin{array}{c}-0.267 \\
(0.93)\end{array}$ \\
\hline Code Mean & $\begin{array}{l}-0.477 \\
(0.92)\end{array}$ & $\begin{array}{c}-0.116 \\
(0.85)\end{array}$ & $\begin{array}{l}0.281 \\
(1.01)\end{array}$ & $\begin{array}{l}0.313 \\
(1.00)\end{array}$ & $\begin{array}{l}0 \\
(1)\end{array}$ \\
\hline
\end{tabular}

Table 15: Human relationship factor: Summary of ANOVA

Source DF Anova SS Mean Square F Value $\operatorname{Pr}>\mathrm{F}$

$\begin{array}{llll}\text { Individual differ. } & 137 & 177.7071403 & 1.2971324\end{array}$

$\begin{array}{llllll}\text { SPEAKER SEX } & 1 & 10.38691844 & 10.38691844 & 9.71 & 0.0022\end{array}$

Error term for $\quad 137 \quad 146.4930889 \quad 1.0692926$

sex effect

CODE

Error term for

$\begin{array}{lllll}3 & 32.37952789 & 10.79317596 & 13.01 & 0.0001\end{array}$

code effect

$411 \quad 340.9130465 \quad 0.8294721$

Total

$551 \quad 550.9997147$ 
Table 16: Power factor: Summary of ANOVA

$\begin{array}{llllll}\text { Source } & \text { DF } & \text { Anova SS } & \text { Mean Square } & \text { F Value } & \operatorname{Pr}>\text { F } \\ & & & & & \\ \text { Individual differ. } & 137 & 123.9435823 & 0.9046977 & & \\ \begin{array}{l}\text { SPEAKER SEX } \\ \text { Error term for }\end{array} & 1 & 8.95832213 & 8.95832213 & 10.74 & 0.0013 \\ \quad 137 & 114.2613960 & 0.8340248 & & \\ \quad \text { cox effect } & & & & & \\ \begin{array}{l}\text { CODE } \\ \text { Error term for }\end{array} & 4 & 39.41698377 & 13.13899459 & 13.93 & 0.0001 \\ \quad \text { code effect } & & 387.6393231 & 0.9431614 & & \\ \begin{array}{l}\text { SEX*CODE } \\ \text { Total }\end{array} & 3 & 7.5362602 & 2.5120867 & & \\ & 551 & 550.9998892 & & & \end{array}$

Table 17: Wit Factor: Summary of ANOVA

$\begin{array}{llllll}\text { Source } & \text { DF } & \text { Anova SS } & \text { Mean Square } & \text { F Value } & \text { Pr }>\text { F } \\ & & & & & \\ \text { Individual differ. } & 137 & 126.3783999 & 0.9224701 & & \\ \text { SPEAKER SEX } & 1 & 39.46172652 & 39.46172652 & 54.86 & 0.0001 \\ \begin{array}{l}\text { Error term for } \\ \quad 137\end{array} & 98.5409741 & 0.7192772 & & \\ \quad \begin{array}{l}\text { CODE effect } \\ \text { Error term for }\end{array} & 3 & 57.70975024 & 19.23658341 & 21.55 & 0.0001 \\ \quad \text { code effect } & 411 & 366.9116939 & 0.8927292 & & \\ \begin{array}{l}\text { SEX*CODE } \\ \text { Total }\end{array} & 3 & 8.7955789 & 2.9318596 & & \\ & 551 & 550.9998441 & 0.9999997 & & \end{array}$

From Table 15 to 17, we find that the four codes play significant roles in making the means different. We therefore did a posteriori comparisons to all possible 6 pairs of comparison in each factor via the Tukey method. In factor I (the human relationship factor), we found that the result is similar to that in Study I, the only difference being that pure Mandarin got a significantly higher mean than the mixing of Mandarin plus English $(p<.05)$. To make a safe summary based on Study I and Study II, to show that s/he is candid, friendly, diligent, socially attractive, and trustworthy, the speaker is suggested to speak in the mixing codes of Mandarin and Taiwanese.

$$
\begin{aligned}
& (\mathrm{M}+\mathrm{T})-(\mathrm{M})=4.696[\mathrm{q} .95(4,549)=3.63 ; \mathrm{q} .99(4,549)=4.40] \\
& (\mathrm{M}+\mathrm{T})-(\mathrm{M}+\mathrm{J})=5.65(\mathrm{p}<.01) \\
& (\mathrm{M}+\mathrm{T})-(\mathrm{M}+\mathrm{E})=8.71(\mathrm{p}<.01) \\
& (\mathrm{M}+\mathrm{E})-(\mathrm{M}+\mathrm{J})=3.05 \text { (n.s. })
\end{aligned}
$$




$$
\begin{aligned}
& (\mathrm{M}+\mathrm{E})-(\mathrm{M})=4.01 \quad(\mathrm{p}<.05) \\
& (\mathrm{M}+\mathrm{J})-(\mathrm{M})=0.95 \text { (n.s.) }
\end{aligned}
$$

As for Factor II (the power factor), the means of the 4 different kinds of codes are not the same as those in Study I. In Study I, the means from the highest to the lowest are $M+E, M, M+T$, and $M+J$; in this study the means from the highest to the lowest are $\mathrm{M}+\mathrm{E}, \mathrm{M}, \mathrm{M}+\mathrm{J}$, and $\mathrm{M}+\mathrm{T}$. The order difference exists in the third and the last. The test of the Tukey method applied to this study is as follows.

$$
\begin{aligned}
& (M+E)-(M)=3.17(\text { n. s }) \\
& (M+E)-(M+J)=3.40 \quad(\text { n.s. }) \\
& (M+E)-(M+T)=8.48(p<.01) \\
& (M)-(M+J)=3.40(\text { n.s }) \\
& (M)-(M+T)=5.31(p<.01) \\
& (M+T)-(M+J)=1.91 \text { (n. s. })
\end{aligned}
$$

Only two pairs have significant differences in means; that is, the mixing of Mandarin and English is significantly better than the mixing of Mandarin plus Taiwanese; pure Mandarin is significantly better than the mixing of Mandarin and Taiwanese. To make a safe summary based on both Study I and Study II, we can suggest that either Mandarin plus English or pure Mandarin is spoken and the mixture of Mandarin plus Taiwanese is avoided to show that the speaker is highly educated, engaged in intellectual jobs not manual ones, authoritative, and wise.

As for Factor III (the Wit factor), in Study I, the means from the highest to the lowest are $M+E, M+T, M+J$, and $M$. In Study II, the means from the highest to the lowest are $M+T, M+E, M+J$, and $M$. The order differences exists in the first two. In this study, as in Study I, the mixing of Mandarin plus English and the mixing of Mandarin plus Taiwanese do not significantly differ from each other. As in Study I, the other five pairs are significantly different from each other; that is, both Mandarin plus Taiwanese and Mandarin plus English got higher means than the mixing of Mandarin plus Japanese and pure Mandarin. The mixing of Mandarin plus Japanese also got a higher mean than the use of pure Mandarin.

$$
\begin{aligned}
& (M+E)-(M)=9.43(p<.01) \\
& (M+E)-(M+J)=4.938(p<.01) \\
& (M+E)-(M+T)=0.385(n . s .) \\
& (M+T)-(M)=9.81(p<.01) \\
& (M+T)-(M+J)=5.323(p<.01)
\end{aligned}
$$


$(\mathrm{M}+\mathrm{J})-(\mathrm{M})=4.49(\mathrm{p}<.01)$

Based on Study I and Study II, we can state that when the speaker mixes Mandarin plus Taiwanese and Mandarin plus English, s/he is seen by the hearers as the most humorous and as one who likes to show off. The use of pure Mandarin shows that the speaker is the least humorous and least likely to show off.

From Tables 15 to 17, we can also conclude that speaker gender has significant effects on all three factors. Generally speaking, when females speak, they are judged to be more friendly and socially attractive than the male counterparts. However, if the mixing of Mandarin and English is neglected, females are judged less educated and less wise than the male counterparts. In the wit factor, females are judged significantly less humorous and less fond of showing off than the male counterparts.

To make a consistent conclusion based on Study I and Study II, females are consistently judged more candid, friendly, socially attractive, diligent, and trustworthy than the male counterparts. Concerning the power factor, we cannot make the judgement that males are judged to be better educated and wiser than the females, because in Study I, males and females are not significantly different while in Study II, the mean difference between males and females is the lowest among the three factors, though it has reached the critical value of $p$-value $<0.05$. Concerning the wit factor, the conclusion is that males are judged to be more humorous and more fond of showing off.

\section{Summary}

Fasold (1984) states that "the study of language attitudes is instructive in its own right, but it is even more valuable as a tool in illuminating the social importance of language." This study can benefit both the permanent residents of Taiwan, especially those who intend to be elected as members of the National Assembly or the Legislative Yuan and those who intend to show that they are experts or who intend to show that they have a good sense of humour. It can benefit the visitors to Taiwan too, the international traders, tourists, etc.

The finding that women are generally considered more friendly, more socially attractive, more diligent, more trustworthy, and more candid than men, and that men are generally thought to be more humorous and fond of showing off is the side-product of the study on code-switching. This proves that in society, there are some stereotypical thoughts about men and women, though men generaily think that women are oversensitive about this.

\section{Suggestions for further study}

El-Dash and Tucker (1975) asked a number of questions about the suitability of the different language varieties for use in several situations in Egypt. The subjects were asked to judge the suitability of each guise, as they heard it, for use: (1) at home; (2) at school; (3) at work; (4) on radio and television; and (5) for formal and 
religious speeches. There were no significant differences among the three guises Classic Arabic (HIGH), Egyptian English (HIGHER), and Colloquial Arabic (LOW) - for the 'at work' situation. Low language - Colloquial Arabic - is by far the most suitable variety for use at home, and High language - Classical Arabic - is least suitable, ranking significantly lower than Egyptian English. At school, on the other hand, Classical Arabic is the most suitable variety, with no difference between Egyptian English and Colloquial Arabic. For use on radio and television and in formal and religious speeches, there is a three-way distinction. Classical Arabic is significantly more suitable than either of the other two, and Egyptian English is significantly more suitable than Colloquial Arabic.

For the situation in Taiwan, our speculation is that at school, on radio and television, for formal speeches, the HIGH language is suitable. At home, at work, and for religious speeches, the mixing of HIGH language (Mandarin) and LOW language (Taiwanese) is suitable. For religious speeches, it is also speculated that maybe different varieties are suitable for different religions; for example, for Buddhism and Taoism, maybe pure Taiwanese is suitable; for Catholics and Christianity maybe the location of the churches play a significant role in choosing the suitable language variety. Surrounding the universities, English or the mixing of Mandarin and English may be suitable; in the countryside, Taiwanese is suitable, and in the city, maybe Mandarin is more suitable. We invite further studies to investigate the influence of activity domains on language attitudes. ${ }^{4}$

\section{References}

Bate, Barbara (1988) Communication and the sexes. New York: Harper \& Row Publishers.

Carranza, Michael and Ryan Ellen Bouchard (1975) Evaluative reactions of bilingual Anglo and Mexican American adolescents towards speakers of English and Spanish. International Journal of the Sociology of Language 6: 83-104.

Cheng, Yuh-show (1989) A preliminary syntactic study on Mandarin/Taiwanese code-switching. Unpublished MA thesis. National Taiwan Normal University.

Cooper, Robert and Joshua Fishman (1974) The study of language attitudes. International Journal of the Sociology of Language 3: 5-19.

Cronbach, L.J. (1951) Coefficient alpha and the internal structure of tests. Psychometrika 16: 297-334.

d'Anglejan, Alison and G. Richard Tucker (1973) Sociolinguistic correlates of speech style in Quebec. In Shuy and Fasold 1973: 1-27.

El-Dash, Linda , and G. Richard Tucker (1975) Subjective reactions to various speech styles in Egypt. International Journal of the Sociology of Language 6: 33-54.

\footnotetext{
${ }^{4}$ We thank for the three instructors, Yu-min Hsiao, Hsi-chi Chen, and Chuei-hwei Shih, at Feng Chia University for excuting the study for us.
} 
Fasold, Ralph (1984) The sociolinguistics of society. New York: Basil Blackwell.

Ferguson, Charles (1959) Diglossia. Word 15: 325-340. Also in Giglioli 1972: 232-51 and in Hymes 1964: 429-439.

Gumperz, John (1977) The sociolinguistic significance of conversational code-switching. RELC Journal 8:2. 1-34.

Hill, Jane and Kenneth Hill (1980) Metaphorical switching in modern Nahuatl: change and contradiction. Papers from the sixteenth regional meeting of the Chicago linguistic society. pp. 121-133. Chicago: Chicago Linguistic Society.

Hymes, Dell (1964) Language in culture and society. New York: Harper and Row.

Kubler, Cornelius (1988) Code switching between Taiwanese and Mandarin in Taiwan. In Robert L. Cheng and Shuanfan Huang (eds.), The structure of Taiwanese: a modern synthesis. Taipei: Crane Book Publishing Co.

Lakoff, Robin (1973) Language and woman's place. Language in Society 2: 45-80.

Lambert, Wallace, R. Hodgson, R. Gardner, and S. Fillenbaum (1960) Evaluative reactions to spoken language. Journal of abnormal and social psychology 60: 44-51.

Lambert, Wallace (1967) A social psychology of bilingualism. Journal of social issues 23:2. 91-109.

Liao, Chao-chih (1992) Code-shifting in the Taiwanese academic setting. Unpublished Manuscript. National Taiwan Normal University.

Lin, Yi-chiou (1987) The social evaluation of Mandarin and Taiwanese in Taipei: a case study of attitudes towards language varieties and language use. Unpublished MA thesis. National Taiwan Normal University.

Osgood, Charles, C. Suci, and Percy Tannenbaum (1957) The measurement of meaning. Urbana: University of Illinois Press.

Parasher, S.N. (1980) Mother-tongue-English diglossia: a case study of educated Indian bilinguals' language use. Anthropological linguistics 22:4. 151-168.

Shuy, Roger and Ralph Fasold (eds.) (1973) Language attitudes: current trends and prospects. Washington, DC: Georgetown University Press.

Tse, John K.P. (1982) Language policy in the Republic of China. In Kaplan (ed.), Annual reviews of applied linguistics 1981, II Pp. 33-47. Rowley, Massachusetts: Newbury House Publishers, Inc.

Tse, John K.P. (1983) Bilingualism in university students in the Republic of China. Studies in English literature and linguistics 9: 178-192.

Yeh, Hsi-nan (1989) The initiation strategy in language choice: a case study in Taipei. Unpublished MA thesis. National Taiwan Normal University. 